\title{
O Uso do Livro Didático na Visão dos Professores da Escola Secundária: considerações gerais*
}

The Use of Textbook in the Point of View of High School Teachers: general considerations

\author{
Milton S. Ribeiro Miltão ${ }^{\dagger}$ \\ Departamento de Física - UEFS \\ Campus Universitário, Km 03, BR 116 \\ Feira de Santana - BA - 44031-460
}

Maria Tereza Moraes Simões, ${ }^{\ddagger}$ Denise Simões Serra, e Tânia Cristina R. Sousa ${ }^{\S}$

Colégio Estadual Mário Augusto Teixeira de Freitas

Salvador - BA-40040-400

\begin{abstract}
Neste trabalho consideramos, a partir do ponto de vista dos professores do segundo grau, a questão do uso dos livros didáticos em sala de aula. Levando em conta as funções do livro, bem como a linguagem subjacente, estabelecemos uma definição para o livro didático e analisamos dez questões, por nós formuladas, tecendo algumas considerações com o objetivo de solucioná-las.
\end{abstract}

Palavras-chave: Livro Didático, Sala de Aula, Comunicação, Linguagem.

In this work we consider the question about the use of textbooks from the point of view of high school teachers. Taking in account the uses of the textbooks, as well as the underlying language, we establish a definition for the textbook and analyze ten questions, formulated by us, about the use of textbooks taking some considerations with the objective to solve them.

\section{Keywords: Textbook, Classroom, Communication, Language.}

\section{INTRODUÇÃO}

A Educação, como estabelecido em Pereira e Foracchi [1], deve ser considerada como um fenômeno social, não sendo para a sociedade senão o meio pelo qual ela prepara, no íntimo dos seres, as condições essenciais da própria existência, ou seja, ela cria no indivíduo um ser

\footnotetext{
*Esse trabalho é resultado de pesquisas desenvolvidas pelos autores enquanto professores (de Física, História, Geografia e Português) de uma escola pública do segundo grau, a Escola Mário Augusto Teixeira de Freitas da cidade de Salvador - BA. A pesquisa foi realizada entre os anos de 1993 e 1996. O autor M.S.R. Miltão também desenvolvia atividades no Colégio Estadual Mário Augusto Teixeira de Freitas, por ocasião da escrita deste trabalho.

${ }^{\dagger}$ Endereço Eletrônico: miltaaao@ig.com.br

${ }^{\ddagger}$ Endereço Eletrônico: simoes.tereza@gmail.com

${ }^{\S}$ Endereço Eletrônico: thanyahealthy@yahoo.com.br
}

novo, um ser social.

Nesse sentido, podemos afirmar que ao utilizar a educação como um meio de socializar os seres individuais, a sociedade também a considera como um processo de controle social [1].

Assim, o ato de educar pressupõe uma ação recíproca entre educador e educando, uma interação. O que implica na existência, entre as partes, de uma ligação, uma passagem, uma convivência, i.e., uma comunicação entre educador e educando. Nesse trabalho pretendemos examinar esse fato, a comunicação entre educador e educando, em particular, o aspecto da utilização da comunicação pelos professores, no que tange ao uso do livro didático.

Não é desconhecida a relação existente entre comunicação e educação. Como assevera Paulo Freire, "a educação é comunicação, é diálogo, na medida em que não é a transferência de saber, mas um encontro de sujeitos interlocu- 
tores que buscam a significação dos significados" [2].

Assumiremos alguns pressupostos para embasar a nossa análise que pautar-se-á (i) na compreensão de uma visão clara e global dos recursos utilizados na comunicação (por exemplo, o livro didático, o vídeo, a televisão, dentre outros) e (ii) na utilização dos meios de comunicação para a formação do ser social, crítico e atuante. São eles:

- No que tange à natureza da atividade de ensino, assumiremos que ela é indissociável das atividades de pesquisa e extensão, pois, consideramos que uma instituição educacional (seja ela creche, $1^{o}$, $2^{\circ}$ ou $3^{\circ}$ graus) deve estar fundada nos pilares do ensino, da pesquisa e da extensão, desenvolvidos integradamente;

- No que tange à concepção de ensinoaprendizagem, assumiremos as pedagogias relacional e de ação cultural, em harmonia com as teorias epistemológicas construtivista e dialógica, pois, consideramos que a interação educadoreducando não pode ser autoritária [3], que o processo de ensino-aprendizagem não deve se esgotar na transmissão do saber, como um caminho, e na avaliação da aprendizagem, como o caminho da volta;

- Por educação relacional-construtivista entendemos aquela [4] que é considerada como um processo de socialização no sentido de se criar condições de cooperação, ou seja, a educação relacional é vista como forma de promover o processo de interação, bem como as relações de reciprocidade;

- Por educação cultural-dialógica ou emancipatória entendemos aquela [4-6] que é considerada como um ato político e como um produto histórico no sentido de criar condições de libertação, ou seja, a educação emancipatória "é vista como forma de promover o processo de conscientização" [5].
Esses aspectos nos servem de égide para a nossa análise do problema do uso do livro didático na sala de aula, livro didático que, de acordo com Luckesi,

"é um meio de comunicação, através do qual o aluno recebe a mensagem escolar" [7],

e cujo papel social, para Escarpit,

"não é mais que o reflexo da sociedade em que se desenvolve" [8].

Assim, nesse trabalho, pretendemos fazer um estudo, a partir de nossa experiência do diaa-dia da sala de aula, sobre a utilização do livro didático pelos professores do segundo grau.

Frisemos que o livro didático, ao nível do $2^{\circ}$ grau, é tema inserido em vasta bibliografia [8-17], contudo, nesses estudos os professores desse nível de ensino não estão presentes como pesquisadores/autores de tais investigações. Eles comparecem, em geral, como objeto de tais estudos, não sendo, portanto, sujeitos participantes que produzem conhecimentos a partir do dia-a-dia na sala de aula, assumindo que as atividades de ensino, pesquisa e extensão são pilares de qualquer instituição educacional.

Sublinhemos, ainda, que o problema do livro didático é um tema atual de pesquisa e que várias questões são levantadas [8-17], em particular, aqueles que se situam ao nível de $1^{o}$ grau, apresentam vários problemas, nomeadamente [14]: (i) apresentam distorções e até erros de informações, bem como conceituais; (ii) sugerem uma inocência de seus leitores; (iii) acrescentam textos desconexos do espaço e do tempo dos seus leitores; (iv) incitam ao preconceito; e (v) apresentam uma visão maniqueísta da realidade.

Como revela a nossa própria experiência, no dia-a-dia da sala de aula, em nossa instituição educacional do segundo grau, tais problemas, aludidos no parágrafo anterior, não são exclusivos do $1^{\circ}$ grau. As nossas motivações, portanto, nesse trabalho, dentre outras, são: (i) como equacionar tais problemas no nosso nível 
de ensino, quando convivemos com profissionais desmotivados e preocupados unicamente em reproduzir as mensagens que estão veiculadas nos livros didáticos? e (ii) sendo os professores formados nas universidades, como estas podem enfrentar esses problemas, particularmente em termos de seus currículos?

\section{COMO DEFINIMOS O LIVRO DIDÁTICO}

Para estabelecermos uma definição sobre o livro didático e que servirá de base para analisarmos as questões sobre o seu uso, nos ancoraremos em mais dois pressupostos: um relacionado com as funções do livro, e o outro relativo a sua linguagem.

A Fundação Biblioteca Nacional estabelece que o livro, basicamente, tem três funções [18]:

- o livro objeto - quando o consideramos um investimento, um elemento de decoração ou um símbolo de status;

- o livro funcional - quando é utilizado para a prática a que se destina; e

- o livro literário - quando proporciona o diálogo entre o autor e o leitor.

Além disso, estabelece Robert Escarpit [8]:

a função do livro permanecerá, como sempre foi, isto é, a possibilidade de ter à mão uma máquina que contém informação, mas que, ao mesmo tempo, tem o mérito de poder ser interrogada livremente por quem quiser. De duas maneiras: uma pode ser puramente informativa (...), [e a outra] a melhor $e$ mais verdadeira (...) será a literária [8].

Nesse sentido, sob o ponto de vista de suas funções assumiremos, nesse trabalho, que o livro didático apresentará as seguintes funções:
1) como objeto, quando fica guardado na estante servindo como enfeite;

2) como funcional, quando é utilizado pelo professor e pelo aluno, possibilitando um aproveitamento informativo [8]; e,

3) como literário, quando possibilita uma utilização projetiva na qual as mensagens invadem o leitor "que responde a esses estímulos escrevendo na sua cabeça, no seu coração, o livro que quiser escrever" [8], refazendo-o.

Para o estabelecimento do segundo pressuposto, torna-se necessário algumas considerações teóricas.

Inicialmente, convém salientar [19] que linguagem é a capacidade comunicativa que têm os seres humanos, usando qualquer sistema de sinais significativos, de expressarem seus pensamentos, sentimentos e experiências.

Além disso, segundo Sapir [20], a linguagem é uma faculdade imensamente antiga da espécie humana e deve ter precedido os elementos mais rudimentares da cultura material. A linguagem é um elemento cultural de um povo. É, ao mesmo tempo, condição essencial para que haja cultura, todo fazer humano que pode ser transmitido de geração a geração. A cultura é a soma de todas as realizações do ser humano.

No aspecto da teoria da linguagem [19-21], temos as seguintes considerações:

- no tocante às funções, tem-se três. São elas, a expressiva ou sintomática, a de sinal, e a de descrição ou de representação;

- em termos de comunicação, supõe-se um emissor que codifica uma mensagem com o objetivo de transmiti-la, por algum canal, a um receptor que, inversamente, realiza uma operação de decodificação;

- em termos de comunicação lingüística, Jacobson [19, 21] estabelece os seguintes elementos, agrupados respectivamente nas três classes de funções da linguagem: 
(i) o destinador ou remetente; (ii) o contexto, a mensagem, o contato, o código; e (iii) o destinatário;

- as funções da linguagem são ligadas com os diferentes elementos da comunicação lingüística como segue:

(i) a função expressiva ou emotiva é aquela centrada no destinador ou remetente,

(ii) a função referencial (desdobramento da função de sinal) é aquela centrada no referente, no contexto,

(iii) a função poética (desdobramento da função de sinal) é aquela centrada na mensagem, evidenciando o lado palpável dos signos,

(iv) a função fática (desdobramento da função de sinal) é aquela centrada no contato ou canal, verificando se o circuito de comunicação funciona,

(v) a função metalingüística (desdobramento da função de sinal) é aquela centrada no código, e,

(vi) a função conativa é aquela centrada no destinatário;

- de acordo com Auroux et al. [21], as formas mais ordinárias da comunicação humana são a incompreensão e o malentendido (a despeito do modelo de Jacobson pressupor que a linguagem humana possua a estrutura de um código e que existam mensagens preestabelecidas perfeitamente codificadas a priori). Assim, a natureza da linguagem humana não é redutível à natureza dos códigos, pois a comunicação é contingente em um contexto contingente, sendo um elemento novo e, não, o conteúdo de um código regido somente por mensagens pre-estabelecidas;

- a parte mais essencial da linguagem humana é a sua natureza inferencial (não demonstrativa, global, e possuidora de acesso livre às informações na memória) e, não, a sua estruturação em código;
- em termos de propriedades, a linguagem humana apresenta as que seguem [21]:

I. dupla articulação - que é a possibilidade de um signo lingüístico ser decomposto de duas maneiras, ou em sons elementares ou em sons combinados,

II. marcação da subjetividade - que é a propriedade da linguagem humana ser falada por sujeitos localizados aqui e agora (hic et nunc) que expressam um ponto de vista sobre o conteúdo, sem exprimir necessariamente uma representatividade a ele, e,

III. criatividade - que é a possibilidade de surgir a novidade, ou seja, a capacidade do ser humano produzir e compreender frases novas.

Nesse sentido, sob o ponto de vista da linguagem, assumiremos nesse trabalho que o livro didático apresentará as seguintes características:

- apresenta um nível de linguagem normalmente culto, mas obediente às normas gramaticais, estando, assim, menos sujeito a variações;

- de acordo com Roman Jakobson [19], a depender da intenção do autor, as mensagens serão organizadas de diferentes formas, variando os tipos de frases, a escolha do vocabulário, etc;

- num texto podem coexistir diversas funções, apesar da predominância de uma delas, orientando a organização verbal;

Sendo o livro didático um meio de comunicação [7], onde o emissor é o seu autor, o receptor é o educando, a mensagem é o conteúdo transmitido, e o veículo de comunicação é o próprio livro e considerando os pressupostos acima, bem como os da seção anterior, podemos definir o livro didático da seguinte forma: 
Um livro didático é aquele que deve ser funcional, i.e., que sirva para algum objetivo específico pré-determinado, que possibilite uma utilização literária, estimulando o leitor a refazê-lo a partir da leitura, e cujas linguagens escolhidas melhor se adeqüem ao êxito de seu objetivo, observando também a natureza inferencial da linguagem humana, levando em conta os seguintes critérios:

(i) deve considerar os pré-requisitos;

(ii) deve ser rigoroso e claro em relação aos conceitos utilizados;

(iii) deve utilizar os elementos culturais da sociedade a que se destina.

\section{QUESTÕES LEVANTADAS SOBRE O USO DO LIVRO DIDÁTICO}

As considerações sobre as funções do livro e a linguagem subjacente, bem como os aspectos teoréticos levantados na introdução, nos indicam, de maneira irretorquível, que, sendo o livro didático uma produção do ser humano, ele é um produto não neutro, estando sujeito às limitações filosóficas, ideológicas e culturais de seus autores. Sua escolha, conseqüentemente, deve ser cuidadosa: é necessário por parte do educador, selecionar criteriosa e criticamente o livro didático a ser adotado, prevalecendo, na escolha, a qualidade e a utilidade, tendo como objetivo adequá-lo ao contexto sócio-econômico e cultural do educando, procurando obter um rendimento máximo possível do aprendizado.

Esses aspectos e a nossa vivência no diaa-dia da sala de aula, nos possibilitaram levantar as seguintes 10 questões acerca do livro didático:

1. a formação dos professores versus o problema da utilização do livro didático;

2. a necessidade de uma definição do significado do livro didático pelo professor, com o objetivo de entender a sua função;

3. a transformação do professor em leitor;
4. os critérios utilizados na adoção do livro didático;

5. a adoção do livro didático como fonte única e verdadeira;

6. a falta de indicações bibliográficas, destacando o trabalho com os livros paradidáticos;

7. a não adoção de qualquer livro didático;

8. a produção maciça de livros didáticos descartáveis;

9. a escola viabilizando a leitura ainda que não exista uma política nacional efetiva; e,

10. o fracasso da escola e a crise da leitura intimamente interligados.

Analisemos, de maneira sucinta, essas questões. Para um aprofundamento maior de nossas considerações, remetemos o leitor ao artigo "Considerações Gerais Sobre o Uso dos Livros Didáticos a partir da Experiência de Professres em Sala de Aula no Nível Médio" [22].

No que se refere à $1^{a}$ questão, três pontos foram levantados: (i) seleção e organização de conteúdos, (ii) formação dos professores, (iii) professores já formados.

No aspecto da seleção e organização, sabemos que o livro didático é um meio no qual os conteúdos estão ordenados. Assim, cabe ao professor que transmite esse saber, utilizá-lo:

como um material exclusivamente auxiliar do seu processo de ensino, assumindo uma posição crítica frente aos conteúdos ali expostos, despertando nos seus alunos o senso crítico necessário para se ler alguma coisa. (...). O livro será o auxiliar do professor no processo de ensino e o auxiliar do aluno no processo de aprendizagem [7]. 
Observemos que, para o professor cumprir essa tarefa de organização e seleção dos conteúdos, bem como da sua estruturação, é necessário que esteja preparado para tal fim, e isso ocorre durante a sua formação, contudo, como assevera Pura Martins,

o que se presencia no nível da literatura da área, bem como dos programas da disciplina didática, é a ausência de um tratamento mais orgânico da questão do conteúdo, especificando o ideário pedagógico, os pressupostos subjacentes às diferentes formas de seleção e organização de conteúdos [23].

No aspecto da formação de professores, deveria ser feito um trabalho a fim de capacitá-lo a preparar um planejamento crítico para que ele, depois de formado, não se limite única e exclusivamente àquele do livro didático.

Um ponto importante, relacionado ainda à formação, é o fato de que os professores não conseguem estimular a leitura dos seus alunos, pois "a maioria (...) está desorientada, sabe que há hoje uma produção significativa de livros (...), que muitas obras chegam às suas escolas, mas não sabe o que fazer com elas" [24]. Observe que esse aspecto está relacionado à formação, em momentos anteriores à etapa universitária, na medida em que, em geral,

os cursos de literatura infantil, que tiveram, limitaram-se a levantar a história, os conceitos e as funções do gênero, sem nenhum contato verdadeiramente com o livro de história ou com poemas infantis [24].

O que coaduna com a observação de Robert Escarpit, sobre a questão da leitura na infância, quando assevera:

parece indiscutivel, e creio firmemente que assim o é, que todos que, durante a sua infância, tiveram à sua disposição livros

ilustrados, quando adultos

tornaram-se leitores mais

sólidos e persistentes do que

aqueles que não os tiveram [8].

No que tange ao último aspecto dessa questão, os professores já formados, acreditamos que periodicamente deveria haver uma atualização para esses professores; que deveria haver uma redução da carga horária em sala de aula para o professor dispor de tempo, na sua escola, e assim participar de atividades de pesquisa; que as escolas deveriam realizar seminários internos; e que deveria haver um intercâmbio destas escolas com as universidades, i.e., as escolas deveriam participar de atividades de extensão.

Para a análise da $2^{a}$ questão, os pontos levantados estão intimamente relacionados com o estudo da segunda seção deste trabalho: (i) a conscientização do significado de livro didático, (ii) a formação dos professores, (iii) a importância da produção de textos.

Acreditamos que, sendo o livro didático um auxiliar do professor no processo ensinoaprendizagem, este devia ter clara consciência do seu significado. Todo professor deveria, do ponto de vista pessoal/acadêmico, estabelecer uma definição do significado de livro didático, com o objetivo de entender a sua função, para depois disso iniciar a sua tarefa de educador. Obviamente, devido à dinâmica da procura do saber, essa definição seria, somente, um parâmetro inicial que o professor melhoraria durante a sua vida acadêmica, buscando a plenitude dela.

Novamente observamos, também aqui, que a boa formação do professor é condição sine qua non para que essa compreensão do conceito de livro didático ocorra. Nesse sentido, os cursos de formação de professores devem criar condições, em seus currículos, que viabilizem não só a leitura crítica de textos, mas fundamentalmente, a produção deles, além de uma compreensão do papel da leitura do ponto de vista do discurso e da linguagem.

No aspecto da produção de textos, por parte dos professores, a sua importância esta assen- 
tada no próprio significado que a escrita tem como linguagem [21]. Assim, se justifica a necessidade de viabilização da produção de textos (a escrita) nos cursos de formação de professores, como aludido mais acima.

$\mathrm{Na}$ abordagem da $3^{a}$ questão, foram levantados os seguintes pontos: (i) como a leitura é considerada no país; (ii) quais os determinantes do afastamento das pessoas, em relação aos livros; (iii) o papel da escola no estimulo à leitura; (iv) a questão curricular dos cursos de magistério e das licenciaturas.

Como Drewnick coloca,

o brasileiro, digam o que quiserem, não costuma ter muita intimidade com os livros. Conhece meia dúzia no $1^{o}$ grau, uma dúzia no $2^{\circ}$ e, quando consuma a proeza de cursar uma faculdade, acaba tomando contato com mais uma dúzia e meia se for obrigado a isso [9].

O que, em geral, leva a que um leitor seja visto por um não leitor como uma pessoa "muito esquisita" [9].

Segundo Elias José,

sabemos que o gosto pela leitura começa cedo, em casa, antes mesmo do processo de alfabetização. (...). Infelizmente, a sociedade não cumpre o seu papel de estimuladora da leitura, não cria bibliotecas para as crianças. A familia prefere os brinquedos apenas, achando sempre caro ou não se importando mesmo com o livro [24].

Yunes [17], estabelece que existem vários determinantes de afastamento das pessoas em relação aos livros e à leitura. Tais determinantes passam:

a) pela iniciação equívoca;

b) pela posição dos livros na escala de valores da tradição cultural; c) pela falta de acesso ao material impresso;

d) pelo papel que os livros desempenham no sistema educacional.

Devido a essa visão da leitura, pela sociedade brasileira, o que faz com que tenhamos um número pequeno de bibliotecas públicas e livrarias em relação ao tamanho continental do país, a escola, como coloca Elias José [16], termina sendo, para uma grande parcela da população, o primeiro local onde acontece o contato com o livro. Sendo assim, a importância da escola, no estímulo à leitura, aumenta grandemente.

No entanto, a escola carrega as limitações da própria sociedade. Nesse sentido, a própria escola não consegue cumprir o seu papel de estimuladora da leitura satisfatoriamente, de onde se infere que os professores, quando alfabetizados e, posteriormente, quando educandos, não são devidamente estimulados à leitura [11] e, por isso, não conseguirão, no ato do processo de ensino-aprendizagem, criar bons leitores.

Esse ciclo só poderá ser quebrado se, na universidade, conseguirmos introduzir, nos cursos de magistério e das licenciaturas, um sentimento de valorização da leitura e da produção de texto, como já frisado na análise da segunda questão, para ser criada a expectativa de transformar os professores em leitores. Além disso, para os professores já formados, uma solução é a reversão de "toda a metodologia da difusão da leitura na escola" [17].

$\mathrm{Na}$ abordagem de $4^{a}$ questão, a nossa experiência, no convívio de nossa instituição educacional, possibilitou levantar os seguintes pontos: (i) o professor escolhe o livro para atender as suas própria falhas; (ii) o conhecimento específico do professor.

Vemos que o primeiro ponto é um reflexo da $1^{a}$ questão, já abordada, acerca da formação dos professores, só que agora, do ponto de vista do conhecimento específico da matéria (ou conteúdo) a ser ministrado. O que mostra a íntima relação dos dois ponto levantados.

Em linhas gerais, segundo Sant'anna e Menegolla, compete ao professor "saber escolher o livro didático para os alunos, que 
estão inseridos numa realidade social, política e econômica" [25]. Além disso:

- o livro deve ser selecionado criteriosamente, mantendo sempre sobre ele uma posição crítica, não só em relação ao conhecimento específico, mas também em relação à carga ideológica que subjaz a todos os livros;

- o professor deve escolher um livro que facilite o processo de ensino-aprendizagem,

- considerando a clareza,

- o rigor das definições e conceitos,

- a estruturação do conteúdo,

- a apresentação do conteúdo,

- a linguagem do conteúdo;

- a escolha deve estar em consonância com os aspectos funcionais e literários aludidos na definição estabelecida; e,

- na medida do possível, deve considerar o custo.

A análise da $5^{a}$ questão, também, revela uma grande limitação dos professores, no que se refere à sua formação específica e, também, à sua formação pedagógica.

Em relação à formação especifica, escolhem os livros através dos quais eles conseguem aprender melhor o conteúdo; em relação à formação pedagógica, não consideram que estes são carregados de pensamento ideológico e que,

portanto, há uma distinção dos conteúdos de ensino para diferentes grupos sociais: para uns (...) reforçam os privilégios, para outros fortalecem os espíritos de submissão e conformismo [26], escamoteando aspectos da realidade.

Ao adotar o livro didático como fonte única e verdadeira, além dessas questões apontadas, o autor do livro assumirá "o papel de emissor principal do conteúdo escolar e o professor, por tabela, [assumirá] aquela mensagem como sua" [7]; ademais, o livro didático deixará de ser um veículo complementar que auxilia o processo ensino-aprendizagem, passando a ser o veículo principal desse processo. Da análise da $4^{a}$ questão, podemos concluir que o livro didático, sendo um meio de comunicação, deve ser utilizado para auxiliar a escolha dos conteúdos a serem ministrados e auxiliar a elaboração do plano de ensino e de aulas. Para isso, é necessário, por parte do professor, o domínio seguro da matéria e bastante sensibilidade crítica dela.

$\mathrm{Na}$ análise da $6^{a}$ questão foram levantados os pontos: (i) formação dos professores; (ii) utilização de vários livros; (iii) elaboração de material didático; (iv) utilização de livros paradidáticos.

O ponto da formação específica relacionase com o fato de que, ao não indicar uma bibliografia, os professores evitam os alunos 'indesejados' que levantam questões mais profundas acerca do tema tratado. A nossa experiência, constatada no dia-a-dia da sala de aula, ao ministrar as aulas das disciplinas de Física, História, Geografia e Português, nos revela que os professores devem adotar vários livros didáticos, inclusive paradidáticos, e devem deixar os seus estudantes livres para a escolha daquele livro que melhor se identifique.

Dessa forma, vemos que os pontos levantados nessa questão estão relacionados. Senão vejamos: no início do ano letivo, os professores devem discutir com os estudantes uma extensa bibliografia, considerando as vantagens e desvantagens de cada um dos livros (o que implica em um bom domínio do conteúdo específico) e deixar livre a escolha por parte deles. Isso implica que os professores devem criar o hábito de preparar o seu próprio material (notas de aula) para garantir uma fluidez e homogeneidade, bem como uma harmonia dos conteúdos apresentados em sala de aula (e que, de certa forma, não apresentariam essas características a partir dos distintos livros sugeridos), explicitando o seu discurso, sua mensagem, utilizando os livros adotados como auxiliares, como veículo complementar, no processo de ensino-aprendizagem.

Nesse sentido, nessa bibliografia apresen- 
tada, devem ser listados, também, os livros paradidáticos, considerando o fato de que tais livros auxiliarão na leitura que é uma ferramenta importante na compreensão dos conteúdos tratados em sala de aula. Ademais, como comprovamos em nossa experiência em sala de aula, os livros paradidáticos são de fácil manuseio; apresentam baixo custo para a sua aquisição; trazem informações e fatos curiosos que instigam a curiosidade, auxiliando tanto o professor, quanto o aluno; em geral, apresentam uma abordagem mais ampla, permitindo correlacionar o conteúdo a ser trabalhado em sala de aula com assuntos de outras disciplinas; e servem como uma fonte de leitura estimulante para os alunos; dentre outras características.

No que concerne à análise da $7^{a}$ questão, a não adoção de qualquer livro didático por parte do professor está fora de discussão devido às considerações que estabelecemos na análise da $6^{a}$ questão, pois concordando com Luckesi,

o livro didático, de forma alguma, deve ser instrumento descartável no processo ensinoaprendizagem. Ele é um instrumento importante, desde que tem a possibilidade de registrar e manter registrada, com fidelidade e permanência, a mensagem. (...). Através do livro, o educando terá a possibilidade de se reportar, quantas vezes quiser, ou necessitar ao conteúdo ensinado na sala de aula [7].

As conseqüências da não adoção do livro didático, entre outras, podem ser:

1. a falta de um referencial para o estudante;

2. a limitação do conhecimento do estudante às apostilas (notas de aula) ou ao conteúdo do professor; e,

3. o perigo na transmissão de conceitos que podem conter incorreções (apesar de que tais incorreções podem estar presentes nos próprios livros didáticos, como foi frisado na introdução).

No que se refere à $8^{a}$ questão, o primeiro ponto a observar relaciona-se com a questão da produção maciça de livros como fonte de lucro [12] pelas indústrias do livro. Esse fato, que é um reflexo da ideologia capitalista interessada sempre em maiores lucros, revela que, em nossa sociedade, o livro didático está se transformando, de um meio para a educação dos indivíduos dessa sociedade, em um produto qualquer de seu bem de consumo. Isso pode facilmente ser comprovado ao lermos os jornais, os quais veiculam que "a indústria do livro didático no Brasil vai de vento em popa, com lucros exorbitantes para os que a exploram em detrimento da educação" [16]. Em conseqüência disso, todo ano, são produzidos centenas de novos títulos, eventualmente, com autores não confiáveis.

Esse é um aspecto que está relacionado com políticas públicas, que é o segundo ponto a ser observado na análise dessa questão:

se houvesse um disciplinamento
por parte do Ministério da
Educação, impedindo que a
cada ano centenas de novos
títulos fossem elaborados, evi-
dentemente as despesas [fami-
liares] com a compra de ma-
terial didático seriam signi-
ficativamente menores no ano
seguinte. Assim, eles pode-
riam passar de irmão para
irmão, numa mesma família.
Poderiam, ainda, ser doados a
estudantes carentes, principal-
mente de escolas mantidas por
instituições filantrópicas [16].

Em geral, muitas dessas novas edições contêm somente modificações da apresentação dos conteúdos, do ponto de vista editorial, como pode ser observado quando manuseamos os exemplares e comparamos com edições anteriores. Não é desconhecido que 
não há razões que justifiquem $o$ lançamento, anualmente, de centenas de novos livros didáticos para todas as disciplinas, embora, na verdade, seu conteúdo seja idêntico, até porque não há como inventar teorias na matemática, na física, etc. Estudos de línguas, por exemplo, independem da mudança freqüente de compêndios [16].

Um terceiro ponto a ser considerado, e que está relacionado com os outros dois pontos aludidos, refere-se à distribuição de livros didáticos pelas grandes editoras/distribuidoras. Como verificamos, no início de cada ano letivo, grandes editoras/distribuidoras, invariavelmente, enviam exemplares para as escolas as quais distribuem entre os professores, o que acaba levando à adoção de livros didáticos sem a necessária análise pedagógica e científica de seus conteúdos. A partir da experiência, por nós vivenciada, acreditamos que a liberdade de escolha por parte do estudante, de seu livro didático, depois da discussão mencionada na análise da $6^{a}$ questão, no início do ano letivo, seria uma forma de minimizar esse problema.

Os pontos levantados na análise da $9^{a}$ questão foram os seguintes: (i) a escola como o local de primeiro contato com a leitura; (ii) a escola falha na tarefa de propiciar a leitura; (iii) inexistência de políticas públicas de leitura; (iv) a leitura como um ato cultural.

Como foi estabelecido na $3^{a}$ questão, a escola termina sendo o local onde a criança tem o primeiro contato com o livro, no entanto, devido às condições das suas bibliotecas e à formação de seus professores, tais instituições educacionais, também, falham na tarefa de introduzir as crianças no mundo da leitura.

Esse é um problema que se torna mais agudo devido à ineficácia de uma política nacional de leitura, como alerta Yunes:

uma rápida avaliação da ação
do Estado na promoção da leitura, nos últimos cinqüenta anos, revela sua falta de decisão política, suas estratégias frouxas, a intermitência e superficialidade dos programas. Boas intenções não bastam. Como também não resolvem campanhas de alfabetização, erro reincidente de projetos salvacionistas [17].

Não é desconhecida a importância dos professores na formação do ato de leitura [10], seja na infância, seja no $1^{\circ}$ ou $2^{\circ}$ graus. Sabemos, também, que não podemos obrigar os nossos educandos à leitura, impondo livros, sejam eles literários e/ou didáticos. Ademais, sabemos da importância que as bibliotecas das escolas têm para despertar o hábito pela leitura nos seus alunos. Como, então, fazer com que a escola viabilize a leitura, se ela, na realidade, ao apresentar esses problemas (condições precárias das bibliotecas e professores com formação deficitária), [17] tem se interposto entre o educando e a obra a ser lida, como um obstáculo? Além disso, como fazer com que a leitura não seja um mero hábito e passe a ser um ato cultural?

Vários são os fatores que levam as escolas a dificultar o ato de ensinar; além dos citados acima, a organização da escola é dos mais preponderantes.

Normalmente, ela não respeita as características individuais das crianças, considerandoas como sendo todas perfeitamente idênticas (...), todas têm o mesmo nível de conhecimento, as mesmas habilidades, os mesmos interesses e motivos, o mesmo ritmo de aprendizagem [25],

ou seja, não leva em conta as características psicológicas das crianças, em desacordo com a literatura especializada [27].

Os fatores aludidos estão, estritamente, ligados com a dificuldade da escola no ato de 
ensinar, viabilizando a leitura. Todavia, criar o hábito de leitura, somente, não é a solução, pois:

a leitura, tal como é conduzida hoje, substitui uma experiência que não pode ser vivida e isso não é suficiente. Por não ter acesso ao mundo cultural mais amplo, a criança não faz a confrontação do que lê com a sua própria realidade. Entre o livro, o universo cultural em que ele é produzido e a realidade da criança não há nada. Ela não tem elementos para a critica [15].

A leitura tem que ser um ato cultural, ou seja, a leitura tem que inquietar o leitor, fazê-lo pensar, sentir e reelaborar; enfim, a leitura, enquanto um ato cultural, está intimamente ligada ao modo de produção do conhecimento humano, o qual se caracteriza por uma permanente interação entre pensar, sentir e fazer: quando lemos devemos pensar nas informações extraídas dos textos, compará-las com o nosso universo cultural, sentindo essa confrontação, e então reelaborar o nosso pensamento (fazer).

Para superar as dificuldades da escola no ato de ensinar e, assim, propiciar a leitura enquanto um ato cultural, ela tem que assumir de vez a atividade de extensão, como um de seus pilares fundamentais, e sair do seu limite físico, atravessar os muros e trazer a sociedade para dentro dela; dessa forma, a convivência no espaço urbano, hoje vetada para os educandos, seria superada e o pensar, sentir, fazer, necessários ao ato da leitura, seriam estabelecidos.

Por fim, mas não menos importante, na análise da $10^{a}$ questão, os pontos levantados foram os seguintes: (i) atividades de pesquisa extensão não cultivadas; (ii) atividade de ensino estática; (iii) política democrática efetiva de ensino e de comunicação inexistentes.

A partir de nossa experiência, na sala de aula, podemos concluir que o fracasso da escola
[28] está ligado, em linhas gerais, ao fato das escolas não assumirem as atividades de pesquisa e extensão, o que leva os professores, mal formados, a restringirem-se na transmissão de um saber já estabelecido, estático, não abrindo perspectiva para a produção de novos conhecimentos; e os alunos, filhos de uma sociedade avessa à leitura, a aceitarem esse saber estabelecido sem resolverem os seus verdadeiros problemas sociais e culturais.

Esses fatos são conseqüências da escassez de uma política democrática efetiva de ensino e de comunicação [17, 29-33], o que não deve impedir tentativas particulares, em seus pequenos universos, de resolução de problemas que estiverem ao seu alcance.

Quando colocamos a necessidade de que as atividades de ensino, pesquisa e extensão sejam cultivadas, de forma indissociáveis nas escolas, como uma forma de enfrentar o problema aludido, da relação entre o fracasso da escola e a crise da leitura, está em nossa mente, não só o significado da natureza de uma instituição educacional que lida com o conhecimento humano, mas a concepção de educação e ensinoaprendizagem que assumimos.

Defendemos a tese de que uma Instituição Educacional, de qualquer nível, é aquela cujos pilares são as atividades de ensino, pesquisa e extensão, e que estas obedecem ao princípio da indissociabilidade, sendo que as suas estruturas acadêmica e administrativa devem estar relacionadas com o cultivo de tais atividades acadêmicas.

Acreditamos que a atividade de ensino, em uma escola, deve ser entendida como um processo relacional e de ação cultural, assentado no pressuposto epistemológico construtivista e dialógico [4, 5], na direção [34] da formação ou modificação da conduta humana, configurandose, assim, como um processo de duas vias: o processo de ensino-aprendizagem, onde os dois atores, o professor e o estudante, interagem na busca de seus objetivos.

A prática dessa atividade, do ponto de vista do professor, significa a convivência com o outro (o estudante), para tentar entendêlo psicológica e socialmente, respeitando as suas virtudes e ajudando a superar as suas la- 
cunas (entendidas como "compreensão mágica ou ingênua da realidade" [35]), "propiciando condições onde possam se estabelecer reciprocidade intelectual e cooperação ao mesmo tempo moral e racional" [4].

Como a nossa própria experiência nos tem mostrado e sistematizando as considerações de Berchem [36] e Demo [37], sobre a ação do professor, para implementar a sua ação pedagógica ele pensa, imagina, descobre, cria situações, atinentes ao seu Campo do Saber, que propiciarão não só o seu planejamento, preparação de aulas, correção de trabalhos e provas, mas, principalmente, propiciarão o bom entendimento das explicações que serão argumentadas em classe ou no atendimento e orientação extra classe, no sentido de fazer com que o estudante trabalhe com mão própria, elabore as suas próprias questões, dedique-se ao seu objeto de estudo, tenha objetividade, examine de forma crítica/refletida as situações que se apresentam, busque sempre possibilidades contrárias, seja autocrítico, tenha prudência na afirmação definitiva, verifique sempre os limites e a validade das afirmações, escute as causas, tenha autonomia intelectual, e tenha compreensão e colaboração mental para compreender o ponto de vista do outro.

Dessa forma, a articulação entre ensino, pesquisa e extensão está presente no processo formativo do estudante, pois, neste processo estão inerentes o processo de produção do conhecimento (pesquisa) e a relação com a própria sociedade (extensão).

Complementando as ponderações sobre a atividade de ensino, trazemos a lume as considerações de Demo, sobre a natureza do conceito de professor e a sua relação com a atividade de pesquisa:

em termos de modernidade tecnológica e educativa - e no fundo, na mais bela tradição educativa - professor definese em primeirússimo lugar pela capacidade de produção própria de conhecimento. Como decorrência necessária, deve ensinar. (...). Não deve haver dicotomia entre pesquisar e ensinar (...): quem pesquisa, deve ensinar, quem ensina, só o pode fazer, porque pesquisa. (...). O mero ensino não combina com o desafio tecnológico, como, no fundo, nunca combinou com educação emancipatória [37].

O que está em consonância com a consideração de Sant'Anna e Menegolla [25], sobre o significado de ser mestre, pois, "o mestre não é aquele que se limita a ensinar, mas aquele que desperta consciências adormecidas, que ajuda a abrir caminhos, que promove a ação desencadeadora de liberdades" [25].

No aspecto da natureza do conceito de professor e a sua relação com a atividade de extensão, reafirmamos as considerações feitas na análise da nona questão, no que tange à garantia de que a leitura se torne um ato cultural; assim, não deve haver dissonância entre a extensão e o ensino. Além disso,

$$
\begin{aligned}
& \text { a formação política do aluno } \\
& \text { pode ser motivada também } \\
& \text { por estratégias extrínsecas ao } \\
& \text { currículo, como atividades } \\
& \text { culturais, iniciativas sociais } \\
& \text { (prestação de serviços à comu- } \\
& \text { nidade), eventos comunitários, } \\
& \text { etc. [37], }
\end{aligned}
$$

as quais o professor pode utilizar no processo de ensino-aprendizagem do aluno, como atividades complementares, porém formativas.

No que tange à atividade de pesquisa acreditamos, por um lado, que ela:

representa a estratégia própria de
produção científica, seja na
descoberta de relações reais ob-
jetivas (são encontradas, não
criadas), seja na construção
de posturas dialéticas que va-
lorizam a história (...), [e por
outro, que ela é um] princípio
educativo, a partir da questão
emancipatória [37].


A pesquisa, então, é compreendida como uma "atitude de vida, ou seja, estratégia básica de auto-construção" [37].

Assim, em termos da importância da pesquisa para a atividade de ensino, nos diz Demo que:

o professor-pesquisador, [ao ser] definido como alguém que [sabe] produzir conhecimento próprio, leva o aluno a fazer o mesmo, mutatis mutandis. [Portanto, a] função do professor não é 'dar aulas', mas fazer o aluno trabalhar com mão própria, sob orientação [37].

Ademais, acreditamos que a extensão deve ser compreendida como o conjunto de atos praticados pela escola no sentido de integrar-se à sociedade, atendendo as finalidades básicas do compromisso político-social e da prática acadêmica, ou seja, a extensão deve ser compreendida como [38]:

uma via de mão dupla, com
trânsito assegurado à comu-
nidade acadêmica que encon-
trará, na sociedade, a opor-
tunidade da elaboração da
práxis de um conhecimento
acadêmico; no retorno à [es-
cola], docentes e discentes
trarão um aprendizado que,
submetido à reflexão teórica,
será acrescido àquele conheci-
mento [39].

A extensão, dessa forma, constitui-se no elemento articulador do ensino e da pesquisa (desenvolvidos a partir da escola) com a sociedade.

Vemos, então, que o fracasso da escola, a despeito de sua causa estar vinculada macroscopicamente com políticas públicas, pode ser enfrentado, no mundo microscópico das escolas, com atitudes propositivas de seus docentes, por exemplo, no âmbito da tentativa da prática das atividades docentes de ensino, pesquisa e extensão de maneira indissociável. Pelo que expusemos na análise dessa questão, essa prática pode possibilitar a emancipação, no sentido da conscientização, dos agentes do processo educativo, os educadores e os educandos, fator importante na superação do fracasso escolar. Uma conscientização que poderá ter como conseqüência, por parte desses agentes, o interesse pela busca do próprio conhecimento acumulado pela humanidade, condição básica para despertar a simpatia, o interesse, pela leitura.

Considerando a análise da questão 9 e a necessidade da leitura tornar-se um ato cultural, nós vimos como a atividade de extensão pode contribuir na solução desse problema a partir da conscientização dos indivíduos de sua capacidade de produção do conhecimento. O poder articulador da extensão, entre as atividades de ensino e pesquisa, já foi aludido, mais acima, o que reforça a afirmativa do parágrafo anterior.

Assim, da tentativa de superação do fracasso escolar, somos levados à possibilidade de superação da crise da leitura.

Reciprocamente, considerando a assertiva de Escarpit acerca da força da leitura dos livros, no que tange às transformações sociais, quando este pesquisador assevera que " $n a$ França, durante o século XIX, o livro foi acertadamente considerado como um instrumento de luta social, de libertação do homem, de libertação do trabalhador" [8], podemos dizer que a leitura poderá ser um fator importante no enfrentamento do próprio fracasso da escola. Talvez, não de forma imediata, mas, quem sabe a médio ou longo prazos. Assim, a atitude plena das atividades de ensino, pesquisa e extensão, pelo que expusemos na análise dessa questão, poderá contribuir na transformação dos agentes do processo educativo em leitores; quando considerarmos a concepção da atividade de ensino por nós defendida, contribuindo, dessa forma, na minimização do fracasso escolar.

Assim, da tentativa de superação da crise de leitura, somos levados à possibilidade de superação do fracasso da escola.

A partir da análise dessas dez questões, por nós levantadas, a respeito do uso do livro 
didático, podemos sistematizar as possíveis alternativas de solução propostas, segundo as nossas perspectivas.

- No aspecto da formação dos professores, como vimos, deveria existir um tratamento mais orgânico da questão dos conteúdos que trabalhasse a sua seleção, estruturação e planejamento crítico. Nas discussões desses pontos, seriam tratadas também as questões relativas à leitura e escrita, enquanto produção do conhecimento, visando estimular, não só os professores em formação, mas os seus futuros alunos para o ato da leitura;

- Em termos dos currículos universitários, isso poderia ser feito nas disciplinas de "Didática" e "Variáveis Educacionais e Pedagógicas do Ensino" (do ponto de vista da discussão teórica desses temas), e nas disciplinas "Instrumentação para o Ensino", "Metodologia para o Ensino" e "Estágio Supervisionado" (do ponto de vista da aplicação prática). Certamente, o estabelecimento por parte dos professores, de uma definição do livro didático seria possibilitado;

- No aspecto da formação geral dos professores, a questão da natureza da atividade docente (nomeadamente, o desenvolvimento indissociável das atividades de ensino, pesquisa e extensão), deveria ser trabalhada nas disciplinas universitárias para que, quando formados, os professores agissem naturalmente como produtores de conhecimento como, de fato, são;

- No aspecto da formação de conteúdos específicos de sua área de atuação, os currículos da licenciatura deveriam tratar, em um grau mais aprofundado, esses assuntos específicos. Em outras palavras, no currículo, além das disciplinas do ciclo básico, referentes aos conteúdos específicos, deveriam existir disciplinas que aprofundassem tais conteúdos específicos em um nível avançado, profissionalizante;

- Em termos dos critérios para a escolha do livro didático, a ser adotado em sala de aula, os professores deveriam considerar os seguintes aspectos:

- seleção criteriosa, com posição crítica (em relação ao conhecimento específico e à carga ideológica subjacente),

- a realidade social, política e econômica dos alunos, e,

- considerar a facilitação do processo de ensino aprendizagem (clareza, rigor das definições e conceitos, estruturação, apresentação e linguagem do conteúdo);

- Defendemos, também, a adoção de vários livros didáticos, com a liberdade para o aluno escolher aquele que melhor se identifique. Os paradidáticos devem ser listados para que os alunos tenham opções alternativas que os auxiliem na compreensão dos conteúdos tratados em sala de aula.

\section{CONCLUSÃO}

No presente trabalho analisamos um importante aspecto sobre o livro didático através de dez questões (formuladas a partir de nossa experiência em sala de aula): a sua utilização em sala de aula.

Estabelecemos alguns pressupostos: (i) em relação à concepção de educação, entendemos que deve ser relacional, com o objetivo de promover o processo de interação e as relações de reciprocidade, e deve ser emancipatória, com o objetivo de propiciar o processo de conscientização; (ii) em relação ao processo de ensino-aprendizagem, entendemos que deve estar assentado sobre a pedagogia relacional e de ação cultural, embasadas pelas epistemologias construtivista e dialógica; (iii) em relação 
à atividade docente, entendemos que os professores, de qualquer instituição educacional, devem praticar, de maneira indissociável, as atividades de ensino, pesquisa e extensão; e (iv) em relação ao livro didático, entendemos que este é um meio de comunicação.

A partir daí, com o objetivo de propor uma definição do livro didático, colocamos mais dois pressupostos: um relativo às suas funções e outro relativo às suas linguagens. Então, levando em consideração a nossa vivência, no dia-a-dia da sala de aula, levantamos as dez questões acerca do livro didático, especificamente em relação ao seu uso.

Da análise dessas questões, acerca do livro didático, podemos concluir que uma forma de tratar grande parte delas é possibilitando a liberdade de escolha do livro-texto por parte do estudante. Essa estratégia levará os professores a uma leitura de grande número de livros, na sua área de conhecimento, o que acarretará uma procura da superação de suas lacunas de formação.

Além disso, para os profissionais em atividade, do ponto vista estrutural, é necessário o corpo docente das escolas assumir as atividades de pesquisa e extensão [40] e, para tal, é importante a realização de seminários, com temas específicos sobre esse assunto, que deverão ser ministrados aos professores com o objetivo de aperfeiçoamento, em busca da compreensão da natureza das atividades de ensino, pesquisa e extensão e da importância delas como pilares de qualquer instituição educacional.

No que tange ao aspecto da formação dos professores, nos cursos de licenciatura, as universidades devem adequar os seus currículos, principalmente, no tocante à visão de que as atividades de ensino, pesquisa e extensão são indissociáveis e formam os pilares das instituições educacionais, sejam elas creche, escola de $1^{o}$ e $2^{o}$ graus ou universidade. Além disso, no aspecto dos conteúdos gerias, as disciplinas deveriam, também, tratar de questões relativas à leitura e escrita, enquanto produção do conhecimento, e no aspecto dos conteúdos específicos, deveriam existir disciplinas que aprofundassem tais conteúdos em um nível mais avançado.

Com esse estudo, a nossa expectativa é contribuir, ainda que ingenuamente, para a discussão sobre o livro didático, visando dar a nossa parcela de ajuda nesse importante tema do conhecimento humano, na busca de novos rumos para a educação.

\section{Agradecimentos}

Gostaríamos de agradecer à Professora Raidalva, Vice-Diretora do turno da tarde do Colégio Estadual Mário Augusto Teixeira de Freitas, por sua visão ampla da concepção de atividade administrativa, o que possibilitou o desenvolvimento do nosso trabalho de pesquisa. Também, gostaríamos de agradecer aos colegas do Colégio que, direta ou indiretamente, participaram das discussões relativas à nossa pesquisa. Principalmente, gostaríamos de agradecer aos estudantes que se incorporaram entusiasticamente no projeto trazendo os seus sonhos e desejos na busca de uma educação mais ampla.
[1] L. Pereira, M.M Foracchi (Org.), Educação e Sociedade. São Paulo: Companhia Editora Nacional (1987).

[2] P. Freire, Extensão ou Comunicação? Rio de Janeiro: Paz e Terra (1983).

[3] L.M.T. Furlani, Autoridade do Professor: meta, mito ou nada disso? São Paulo: Cortez e Autores Associados (1988).

[4] M.G.N. Mizukami, Ensino: as Abordagens do Processo. São Paulo: EPU (1986).
[5] W. de Faria, Teorias de Ensino e Planejamento Pedagógico. São Paulo: EPU (1987).

[6] V.A. de Lima, Comunicação e Cultura: as Idéias de Paulo Freire. Rio de Janeiro: Paz e Terra (1981).

[7] C.C. Luckesi, Filosofia da Educação. São Paulo: Cortez (1990).

[8] Biblioteca Salvat de Grandes Temas, O Livro Ontem, Hoje e Amanhã. Rio de Janeiro: Salvat do Brasil (1979). 
[9] R. Drewnick, Tipos muito esquisitos: Como quem lê é visto por quem não lê. Veja Bahia, Salvador 06 jan. (1993).

[10] P. França, A Literatura entre o Gosto $e$ a Obrigação. Revista Leia Ano XI, (127) (1989).

[11] M. Lajolo, Como Transformar Alfabetizados em Leitores. Sala de Aula Ano 3, (22) (1990).

[12] A.M. Maia, O Livro como Lucro. A Tarde, Salvador (1990).

[13] S. Meserani, Para viciar seu aluno. Nova Escola Ano V, (1990).

[14] P. Moreira, Livros Didáticos Idiotizam os Alunos. A Tarde, Salvador (1994).

[15] E. Perroti, A Escola não está formando leitores críticos. Nova Escola Ano V, (1990).

[16] A Tarde, O Problema do Livro Didático. A Tarde, Salvador (1994).

[17] E. Yunes, Por uma Política de Leitura. Nova Escola Ano V, (45) (1990).

[18] Biblioteca Nacional, Notas de Aula do Curso de Conservação, Preservação e Restauração. Rio de Janeiro: PLANOR, Fundação Biblioteca Nacional (1991).

[19] R. Jakobson, Lingüistica e Comunicação. São Paulo: Cultrix (1977).

[20] E.S. Sapir, A Linguagem. São Paulo: Perspectiva (1980).

[21] S. Auroux, J. Deschamps, D. Kouloughli, La Philosophie du Langage. Paris: PUF (1996).

[22] M.S.R. Miltão, M.T.M. Simões, D.S. Serra, T.C.R. Sousa, Considerações Gerais Sobre o Uso dos Livros Didáticos a partir da Experiência de Professores em Sala de Aula no Nível Médio. Caderno de Física da UEFS 04, (01 e 02) 51 (2006).

[23] P.L.O. Martins, Conteúdos Escolares: A Quem Compete a Seleção e Organização? In: A.O. Lopes, I.P.A. Veiga, Repensando à Didática. Campinas: Papirus (1991).

[24] E. José, Professor que não Sabe Ler não Sabe Ensinar a Ler. Sala de Aula 03, (26) (1990).

[25] I.M. Sant'Anna, M. Menegolla, Didática: Aprender a Ensinar. São Paulo: Edições Loyola (1991).

[26] J.C. Libâneo, Didática. São Paulo: Cortez (1992).

[27] C. Davis, Z. de Oliveira, Psicologia na Educação. São Paulo: Cortez (1990).

[28] Nota: por Fracasso Escolar queremos dizer, dentre outras coisas, o não cumprimento do papel social da escola, a grande evasão dos estudantes, os altos índices de reprovação, o fracasso no domínio da leitura e escrita, a falta de capacidade da escola em lidar com a diver- sidade cultural dos alunos, a má formação dos professores, a falta de reconhecimento profissional dos professores por parte das autoridades competentes, o descaso com a escola de modo geral.

[29] L.A. Cunha, M. de Góes, O Golpe na Educação. Rio de Janeiro: Zahar (1989).

[30] M.L.S. Ribeiro, História da Educação Brasileira. São Paulo: Cortez (1990).

[31] O.O. Romanelli, História da Educação no Brasil. Petrópolis: Vozes (1988).

[32] I.O. Soares, A Nova LDB e a Comunicação: perspectivas profissionais para o terceiro milênio. Universidade 1, (1) 46 (1994).

[33] V.V.A.A. Por uma Política Democrática da Comunicação. São Paulo: Paulinas (1993).

[34] Nota: Entendendo direção como uma dimensão que tem dois sentidos.

[35] P. Freire, Educação como Prática de Liberdade. São Paulo: Paz e Terra (1996).

[36] T. Berchem, A missão da Universidade na formação e no desenvolvimento culturais: a diversidade no seio da Universidade. Educação Brasileira 13, (27) 81 (1991).

[37] P. Demo, Qualidade e modernidade da Educação Superior: discutindo questões de qualidade, eficiência e pertinência. Educação Brasileira 13, (27) 35 (1991).

[38] Nota: Adaptação do conceito de extensão estabelecido no texto da UnB [39].

[39] UnB, Extensão - a universidade construindo saber e cidadania. Documento final do I Encontro de Pró-Reitores de Extensão das Universidades Brasileiras (1987). Brasília (1989).

[40] Nota: Como um exemplo de atividades de pesquisa e extensão desenvolvidas por docentes de uma instituição do segundo grau, podemos citar o trabalho intitulado "Estudo do Uso do Livro Didático, Televisão, Vídeo, Cinema e Teatro na Sala de Aula", por nós desenvolvido no Colégio M. A. Teixeira de Freitas, em Salvador, durante os anos de 1993 a 1996. O objetivo do trabalho foi analisar determinados conteúdos veiculados no livro didático, na televisão, em vídeo, no cinema ou no teatro, com o fito de utilizá-los na sala de aula. Resultados parciais foram apresentados na Semana Pedagógica do Colégio M. A. Teixeira de Freitas [41, 42] e foram aceitos para apresentação na $46^{a}$ Reunião Anual da SBPC em 1994. No entanto, por falta de um apoio efetivo do Colégio, não foi possível o deslocamento para a apresentação do trabalho no evento promovido pela SBPC. Um ponto importante a ser ressaltado foi o pio- 
neirismo do desenvolvimento do projeto, na Escola em questão, no aspecto de ser uma atividade de pesquisa desenvolvida por professores de uma instituição educacional do segundo grau. Após um árduo trabalho, em 1996 a direção da escola reconheceu a importância da atividade aprovando-a e divulgando-a pela Portaria 03/96 de março de 1996. No aspecto da orientação a estudantes, faziam parte desse projeto alunos cuja participação, em linhas gerais, se dava a partir de discussões relacionadas aos conteúdos, por eles apreendidos em decorrência da leitura de algum livro didático, de algum programa veiculado na televisão, em vídeo, no cinema ou no teatro e seus possíveis aproveitamentos como conteúdos na sala de aula. Além disso, os alunos produziam um jornal, por nós assessorado, de pequena circulação interna à escola, onde as matérias, desenhos e cartuns relacionavam-se com os temas discutidos sobre os conteúdos por eles apreendidos. As discussões relativas ao trabalho ocorriam em reuniões, no próprio Colégio, com os docentes e no Passeio Público e na Biblioteca dos Barris, com os estudantes, sempre fora do horário das aulas.

[41] M.S.R. Miltão, Abordagem Crítica sobre o Livro Didático. In: Semana Pedagógica do ano letivo de 1994 do Colégio Estadual M. A. Teixeira de Freitas, Palestra. Salvador: Secretaria de Educação e Cultura do Estado da Bahia (1994).

[42] M.S.R. Miltão, Um Estudo Crítico do uso da Televisão e Vídeo na Sala de Aula. In: Semana Pedagógica do ano letivo de 1995 do Colégio Estadual M. A. Teixeira de Freitas, Palestra. Salvador: Secretaria de Educação e Cultura do Estado da Bahia (1995). 